\title{
Experimental substantiation of the use of a small dose of the vaccine to prevent the specific brucellosis of cattle
}

\author{
Aleksei Alekseevich Novitsky ${ }^{1}$, Valentina Ivanovna Pleshakova ${ }^{1}$, Nadezhda Alekseevna Lescheva ${ }^{1, *}$, and Vasilii Sergeevich \\ Vlasenko $^{1,2}$ \\ ${ }^{1}$ Veterinary Microbiology, Infectious and Invasive Diseases Department, Omsk State Agrarian University named after P.A. Stolypin, \\ 644008 Omsk, Russia \\ 2 Veterinary Medicine Department, Omsk Agrarian Scientific Center, 644001 Omsk, Russia
}

\begin{abstract}
The expansion of zones with the cattle without anti-brucellosis immunity in healthy areas increases the risk of cattle infection from neighboring infected regions and states. There is an urgent problem of developing the anti-brucellosis immunity in the adult cattle. The initial full-dose vaccination with the vaccine from strain B. abortus 82 is fraught with post-vaccination abortion. The study is aimed at the exploration of the immune response and immunity in cows vaccinated against brucellosis according to different schemes with small doses of vaccines from B. abortus strains 19 and 82 . The results of the experiment showed that the small-dose revaccination with a vaccine from strain 82 is the most promising, because without any harm to the formed immunity, the problem associated with the reactogenicity and agglutinogenicity of the vaccine can be solved. In addition, a ten-time reduction in the vaccine dose can reduce vaccine production volumes and decrease financial expenses of the farmers.
\end{abstract}

\section{Introduction}

The scientifically-based system of special preventive measures against cattle brucellosis was developed at the end of the 20th century by several research institutes: the Federal Center for Toxicological, Radiation and Biological Safety in Kazan; the Institute of Experimental Veterinary Medicine of Siberia and the Far East; the AllRussian Research Institute of Brucellosis and Animal Tuberculosis, which made it possible to radically improve the epizootic brucellosis-related situation in Russia and classify this disease as a controlled infection.

First of all, it was possible due to the strict schedule of specific preventive measures with the use of the antibrucellosis vaccine made from B. abortus 82 strain. As a result, the number of infected areas was sharply reduced, and most regions and republics were found to be brucellosis-free. However, the epizootiologically justified mass immunization of cattle with a live anti-brucellosis vaccine from strain 82 in infected territories during the period of widespread brucellosis cases became no longer adequate for healthy regions from both an environmental and economic points of view. In this regard, in some healthy areas, the specific preventive measures against brucellosis were completely stopped or conducted only in relation to young animals.

At the same time, appreciating the improvement of the epizootic situation in relation to cattle brucellosis in the whole country, we cannot but pay attention to the fact that the expansion of areas with animals that have not been vaccinated against brucellosis increases the risk of infection because of neighboring infected territories whose farming business is closely related. This circumstance justifies the need for further specific preventive measures in regions with short healthy periods or in regions bearing a risk of infection from neighboring regions or countries [1-3].

The reduction in immunization, both for environmental reasons and due to a sharp decrease in the number of livestock, has made some changes not only in the system of special anti-brucellosis measures, but also in the output plans of biological enterprises specializing in the production of vaccines, in particular, the vaccine from strain 82. The rise in the price of the vaccines has become another reason for farmers to cut down the vaccine purchasing volume or even to refuse to buy it.

Based on the above mentioned circumstances, we define the purpose of our study as follows: to test the scheme of special preventive measures against cattle brucellosis with the use of the vaccine made from strain 82 in small doses, which allows minimizing negative side effects after vaccination, without any immunity decrease. Also, there are some financial advantages of the suggested scheme for the farmers due to the use of the vaccine in small doses.

One of the reasons for reducing the dose of the vaccine is the proliferation ability of live vaccines. To some extent, this ability makes it possible to exclude a strict correlation between the dose of the injected vaccine determined by the number of microbial cells (m.c.) and the formed immunity level. The doses of vaccines from strains 19 and 82 used in the veterinary practice,

Corresponding author: na.lescheva@ omgau.org 
regardless of the puberty of the immunized cattle, are 80 and 100 billion m.c., respectively. In the available literature and in regulatory documents, there is no clear justification for such doses.

In the 1980s, much research was done aimed to test a small dose of the vaccine from strain 19 [4-11]. First of all, there was a need to solve the problem of prolonged seropositivity in animals vaccinated with this vaccine, which complicated the post-vaccination diagnosis of brucellosis in cattle. Currently, in the specific antibrucellosis vaccination schemes, only young cattle is allowed to be vaccinated with the vaccine from strain 19 due to the fact that the synthesis of post-vaccination antibodies is extinguished in the 5-month-old young cattle $[12,13]$. At the same time, vaccination with a small dose of the vaccine ( 3 billion m.c.) allowed the reduction of the age up to 3 months old. Positive results were obtained from the immunization of animals with a small dose of vaccine from strain 19 (4 billion m.c.) using the conjunctival method.

\section{Research Methods}

In the Russian Federation, vaccines from B. abortus strains 19 and 82 are officially used for vaccination of the cattle against brucellosis, so small doses of the vaccine from strain 82 were tested in comparison with the schemes officially adopted in the veterinary practice [14, 15]. The research was conducted in one of the farms of the North Kazakhstan region. Comparative testing of antigenic and immunogenic properties of vaccines from agglutinogenic strain 19 and weakly agglutinogenic strain 82 in different doses was carried out according to 6 schemes (table 1).

Immunization schemes 1 and 3 are currently officially used in the veterinary practice in the Russian Federation according to the instructions. The other schemes are experimental. The inclusion of a vaccine from strain 19 in the experiment is justified by the fact that the use of this vaccine is regulated to create grund-immunity in young animals in the most difficult epizootic conditions for brucellosis.

The dynamics of post-vaccination reactions was studied in experimental groups of animals kept on brucellosis-free farms. A total of 288 cows (45-50 heads in each group) were subjected to research using AT, CFT and RBT. Animals from group 1 to group 4 were examined within 14, 33, 60, and 270 days after vaccination. Animals of group 5 after 14, 32, 182 days, and group 6 after 42, 96,156, 180 days. In order to test the strength of immunity, 5 heads from each group were infected with a virulent culture of $B$. abortus in doses of 100 and 200 million m.c.

\section{Results}

Preliminary study of heifers showed that a full dose of the vaccine from strain 82 stops antibody synthesis by 3 , and a small dose by 2 months.

The dynamics of post-vaccination reactions in cows of a successful herd is shown in table 2 .

From the above data, a significant difference in the degree of manifestation of the compared immunological reactions is visible. In almost all groups of animals and in all periods of the study, the Agglutination Test (AT) indicators were prevailing. Out of 1305 blood serum samples studied, AT indicators were found in 409 cases (31.3\%), Complement Fixation Test (CFT) indicators were found in 203 cases $(15.5 \%)$ and almost the same number of Rose-Bengal Test (RBT) indicators were found in 229 cases $(17.5 \%)$. It should be noted that the AT indicators completely included the RBT indicators, and there was no particular correlation between the AT titer and positive RBT.

The immune response in each group of animals differed. The cattle that were immunized only with the vaccine from strain 82 had the fastest immune response (Schemes 1 and 2). Antibodies were recorded in all animals only on the 14th day. The level of agglutinin production was much higher in cows vaccinated according to Scheme 1.

Other results were obtained in groups where heifers were primarily vaccinated with a vaccine from strain 19 , and then revaccinated before mating and after calving with a vaccine from strain 82 , and the last vaccination was also carried out with different doses (Schemes 3 and 4).

The primary sensitization after the injected vaccine from strain 19 was expressed by a more active immune response, if compared with the two previous schemes. In some animals, antibodies were recorded before the 33rd day and with weak indicators even before the 60th day. As expected, the maximum immune response was with the full dose of the vaccine. It should be noted that if we take into account AT in the titer of $50 \mathrm{IU}$, then in the both groups, $100 \%$ cows had the immune response. Thus, the re-immunization of cows both with the full and small doses of the vaccine from strain 82 provided a short-term immune response detected by serological methods.

Table 1. Cattle vaccination schemes with different doses of vaccines

\begin{tabular}{|l|l|l|l|}
\hline \multirow{2}{*}{ Scheme No } & \multicolumn{3}{|c|}{ Age, strain, dose } \\
\cline { 2 - 4 } & $3-5$ months old & $16-18$ months old & After calving \\
\hline & & 82 f.d. & 82 f.d. \\
2 & 82 f.d. & 82 f.d. & 82 sm.d. \\
3 & 82 f.d. & 82 f.d. & 82 sm.d. \\
4 & 19 f.d. & 82 f.d. & 19 sm.d. \\
5 & 19 f.d. & 19 sm.d. & 19 sm.d. \\
6 & 19 f.d. & 19 f.d. & \\
7 control & 19 f.d. & & \\
\hline
\end{tabular}

Note: f.d.- full dose of vaccine, sm.d. - small dose of vaccine 
Table 2. The dynamics of the formation of post-vaccination antibodies detected by AT, CFT, RBT

\begin{tabular}{|c|c|c|c|c|c|c|c|c|c|}
\hline \multirow{3}{*}{$\begin{array}{l}\text { Vaccination } \\
\text { scheme }\end{array}$} & \multirow{3}{*}{$\begin{array}{c}\text { Number of } \\
\text { cattle }\end{array}$} & \multirow{3}{*}{$\begin{array}{l}\text { Testing } \\
\text { period, in } \\
\text { days }\end{array}$} & \multicolumn{7}{|c|}{ Had reactions, $\%$} \\
\hline & & & \multicolumn{2}{|c|}{ AT, IU } & \multirow[t]{2}{*}{ CFT positive } & \multirow[t]{2}{*}{ RBT } & \multicolumn{2}{|c|}{ RBT corresponds to } & \multirow[t]{2}{*}{ Total } \\
\hline & & & $\begin{array}{l}100 \text { and } \\
\text { more }\end{array}$ & 50 & & & AT & CFT & \\
\hline No 1 & 49 & $\begin{array}{l}14 \\
33 \\
60 \\
270\end{array}$ & $\begin{array}{l}- \\
73.5 \\
- \\
-\end{array}$ & $\begin{array}{c}26.5 \\
2.0 \\
- \\
-\end{array}$ & $\begin{array}{l}10.2 \\
- \\
- \\
-\end{array}$ & $\begin{array}{l}46.9 \\
- \\
- \\
-\end{array}$ & $\begin{array}{l}100.0 \\
- \\
- \\
-\end{array}$ & $\begin{array}{l}21.7 \\
- \\
- \\
-\end{array}$ & 100 \\
\hline No 2 & $\begin{array}{l}- \\
50\end{array}$ & $\begin{array}{l}14 \\
33 \\
60 \\
27\end{array}$ & $\begin{array}{l}34.0 \\
- \\
- \\
-\end{array}$ & $\begin{array}{r}66.0 \\
- \\
- \\
-\end{array}$ & $\begin{array}{l}- \\
12.0 \\
- \\
-\end{array}$ & $\begin{array}{l}26.0 \\
- \\
- \\
-\end{array}$ & $\begin{array}{l}100.0 \\
- \\
- \\
-\end{array}$ & $\begin{array}{l}7.6 \\
- \\
- \\
-\end{array}$ & $\begin{array}{l}100.0 \\
-\end{array}$ \\
\hline No 3 & 50 & $\begin{array}{l}14 \\
33 \\
60 \\
270\end{array}$ & $\begin{array}{l}74.0 \\
18.0 \\
- \\
-\end{array}$ & $\begin{array}{l}16.0 \\
30.0 \\
8.0 \\
-\end{array}$ & $\begin{array}{l}68.0 \\
40.0 \\
- \\
-\end{array}$ & $\begin{array}{l}60.0 \\
30.0 \\
- \\
-\end{array}$ & $\begin{array}{l}100.0 \\
100.0 \\
- \\
-\end{array}$ & $\begin{array}{l}- \\
66.6 \\
- \\
-\end{array}$ & $\begin{array}{l}100.0 \\
60.0 \\
8.0 \\
-\end{array}$ \\
\hline No 4 & 49 & $\begin{array}{l}14 \\
33 \\
60 \\
270\end{array}$ & $\begin{array}{l}42.2 \\
2.0 \\
- \\
-\end{array}$ & $\begin{array}{r}48.9 \\
10.2 \\
- \\
-\end{array}$ & $\begin{array}{l}42.8 \\
- \\
- \\
-\end{array}$ & $\begin{array}{l}53.6 \\
- \\
- \\
-\end{array}$ & $\begin{array}{l}100.0 \\
- \\
- \\
-\end{array}$ & $\begin{array}{l}38.4 \\
- \\
- \\
-\end{array}$ & $\begin{array}{l}100.0 \\
12.2 \\
- \\
-\end{array}$ \\
\hline No 5 & 45 & $\begin{array}{l}14 \\
32 \\
182\end{array}$ & $\begin{array}{l}80.9 \\
57.0 \\
-\end{array}$ & $\begin{array}{r}13.2 \\
22.0 \\
-\end{array}$ & $\begin{array}{l}99.2 \\
66.0 \\
8.8 \\
\end{array}$ & $\begin{array}{l}85.8 \\
59.4 \\
8.9\end{array}$ & $\begin{array}{l}100.0 \\
70.3 \\
-\end{array}$ & $\begin{array}{l}95.0 \\
77.7 \\
25.0\end{array}$ & $\begin{array}{l}100.0 \\
100.0 \\
13.2\end{array}$ \\
\hline No 6 & 45 & $\begin{array}{l}42 \\
96 \\
150 \\
180\end{array}$ & $\begin{array}{l}37.4 \\
6.6 \\
17.6 \\
8.8\end{array}$ & $\begin{array}{l}46.1 \\
46.1 \\
37.4 \\
30.8\end{array}$ & $\begin{array}{l}39.6 \\
13.2 \\
22.0 \\
6.6\end{array}$ & $\begin{array}{l}66.0 \\
30.1 \\
11.0 \\
8.0\end{array}$ & $\begin{array}{l}85.8 \\
68.4 \\
80 . \\
75.0\end{array}$ & $\begin{array}{l}50.2 \\
43.2 \\
20.0 \\
50.0\end{array}$ & $\begin{array}{l}90.2 \\
63.8 \\
55.0 \\
39.9\end{array}$ \\
\hline
\end{tabular}

Being re-immunized with the agglutinogenic vaccine from strain 19 with a small dose, the cattle reacted more actively and continuously (Schemes 5 and 6). For example, in the group of cows that were vaccinated with a full dose of vaccine from strain 19 at the age of 3-4 months old, and then again before mating and after calving with a small dose of this vaccine, antibodies were recorded before the 182 nd day after the vaccination: they were detected by RBT in 4 animals and CFT in 3 animals.

The same indicators of these reactions were noted at this time in the group of cows that were immunized with a small dose of the vaccine, but in comparison with the double sensitization of heifers with a full dose (at the age of 3-4 months old and before mating). The difference in the immune response of the animals of these two groups was only in the fact that the double full-dose vaccination stimulated the synthesis of agglutinins detected 6 months later by AT in $68.8 \%$ of cows in high titer and in $30.8 \%$ of cows in low titer with negative indicators in this period in the previous group.

Thus, revaccination of cows both with full and small doses of the vaccine from strain 82 equally provided a short-term immune response detected by serological methods, which is important for the early post-vaccination diagnosis of brucellosis. At the same time, the small-dose vaccination scheme with the vaccine from strain 19 with the double vaccination is not very promising due to the long-term production of post-vaccination antibodies, which delays diagnostic testing.

Upon completion of the study of the dynamics of postvaccination reactions, 5 animals from each group were vaccinated with a virulent culture of $B$. abortus with the doses of 100 and 200 million m.c. The sensitivity of the compared reactions in the dynamics of the infectious process in the control and experimental groups is shown in Table 3.

The table shows that for the early diagnosis of brucellosis in cows of the control groups, the most preferable is AT: the infection caused a primary immune response in cows. On the 7 th day, $40 \%$ of animals vaccinated with a dose of 100 million m.c. had diagnostic titers with negative indicators of CFT and RBT. Also, more animals $(30 \%)$ vaccinated with a larger dose had the immune response during this period versus $10 \%$ and $20 \%$ of animals.

In total, over the entire indicated period of the study in all groups, $79.2 \%$ of animals had the immune response detectable by AT, $66.1 \%$ of animals had the immune response detectable by CFT and $71.7 \%$ of animals had the immune response detectable by RBT. For comparison, it should be noted that in four groups of cows that were revaccinated with the vaccine from strain 82 , the diagnostic indicators of AT, CFT and RBT were, respectively, in $83.2 \% ; 89.1 \% ; 78.2 \%$ of animals. 
Table 3. The sensitivity of serological methods in cows immunized with various anti-brucellosis vaccines after vaccination.

\begin{tabular}{|c|c|c|c|c|c|c|}
\hline \multirow{3}{*}{$\begin{array}{l}\text { Vaccination } \\
\text { scheme }\end{array}$} & \multirow{3}{*}{$\begin{array}{l}\text { Dose of infection, } \\
\text { mln m.c. }\end{array}$} & \multirow{3}{*}{$\begin{array}{l}\text { Testing period, } \\
\text { in days }\end{array}$} & \multicolumn{4}{|c|}{ Had reactions, $\%$} \\
\hline & & & \multicolumn{2}{|c|}{ AT, IU } & \multirow[t]{2}{*}{ CFT positive } & \multirow[t]{2}{*}{ RBT } \\
\hline & & & 100 and more & 50 & & \\
\hline Control & 100 & $\begin{array}{l}7 \\
15 \\
21 \\
29 \\
41\end{array}$ & $\begin{array}{l}20 \\
80 \\
80 \\
100 \\
60\end{array}$ & $\begin{array}{l}20 \\
- \\
20 \\
- \\
40\end{array}$ & $\begin{array}{l}- \\
60 \\
100 \\
100 \\
60\end{array}$ & $\begin{array}{l}100 \\
60 \\
100 \\
100 \\
100\end{array}$ \\
\hline Control & 200 & $\begin{array}{l}7 \\
14 \\
28 \\
39\end{array}$ & $\begin{array}{l}20 \\
100 \\
86,7 \\
-\end{array}$ & $\begin{array}{l}10 \\
- \\
13,3 \\
100\end{array}$ & $\begin{array}{l}10 \\
100 \\
100 \\
100\end{array}$ & $\begin{array}{l}20 \\
100 \\
100 \\
100\end{array}$ \\
\hline No1 & 200 & $\begin{array}{l}7 \\
14 \\
28 \\
39\end{array}$ & $\begin{array}{l}50 \\
75 \\
75 \\
50\end{array}$ & $\begin{array}{l}25 \\
25 \\
25 \\
25\end{array}$ & $\begin{array}{l}100 \\
100 \\
100 \\
75\end{array}$ & $\begin{array}{l}50 \\
100 \\
100 \\
100\end{array}$ \\
\hline No 2 & 200 & $\begin{array}{l}7 \\
14 \\
28 \\
39\end{array}$ & $\begin{array}{l}80 \\
80 \\
100 \\
-\end{array}$ & $\begin{array}{l}- \\
20 \\
- \\
20\end{array}$ & $\begin{array}{l}60 \\
100 \\
100 \\
100\end{array}$ & $\begin{array}{l}80 \\
100 \\
100 \\
100\end{array}$ \\
\hline No 3 & 100 & $\begin{array}{l}7 \\
15 \\
21 \\
29 \\
41\end{array}$ & $\begin{array}{l}20 \\
20 \\
60 \\
20 \\
40\end{array}$ & $\begin{array}{l}40 \\
40 \\
40 \\
80 \\
40\end{array}$ & $\begin{array}{l}80 \\
80 \\
100 \\
60 \\
80\end{array}$ & $\begin{array}{l}40 \\
100 \\
60 \\
80 \\
60\end{array}$ \\
\hline No 3 & 200 & $\begin{array}{l}7 \\
14 \\
28 \\
39\end{array}$ & $\begin{array}{l}40 \\
80 \\
60 \\
-\end{array}$ & $\begin{array}{l}20 \\
20 \\
40 \\
40\end{array}$ & $\begin{array}{l}60 \\
60 \\
100 \\
60\end{array}$ & $\begin{array}{l}80 \\
100 \\
100 \\
40\end{array}$ \\
\hline No 4 & 200 & $\begin{array}{l}7 \\
14 \\
28 \\
39\end{array}$ & $\begin{array}{l}20 \\
80 \\
60 \\
20\end{array}$ & $\begin{array}{l}- \\
20 \\
40 \\
20\end{array}$ & $\begin{array}{l}60 \\
80 \\
100 \\
100\end{array}$ & $\begin{array}{l}40 \\
100 \\
100 \\
60\end{array}$ \\
\hline No 5 & 200 & $\begin{array}{l}7 \\
14 \\
28 \\
39\end{array}$ & $\begin{array}{l}40 \\
80 \\
80 \\
-\end{array}$ & $\begin{array}{l}40 \\
20 \\
20 \\
20\end{array}$ & $\begin{array}{l}100 \\
100 \\
100 \\
60\end{array}$ & $\begin{array}{l}100 \\
100 \\
100 \\
100\end{array}$ \\
\hline No 6 & $\begin{array}{l}200 \\
-\end{array}$ & $\begin{array}{l}7 \\
14 \\
28 \\
39\end{array}$ & $\begin{array}{l}80 \\
100 \\
80 \\
20\end{array}$ & $\begin{array}{l}20 \\
- \\
20 \\
20\end{array}$ & $\begin{array}{l}100 \\
100 \\
100 \\
100\end{array}$ & $\begin{array}{l}100 \\
100 \\
100 \\
100\end{array}$ \\
\hline
\end{tabular}

Table 4. Schemes for immunizing cows before infection

\begin{tabular}{|c|c|c|c|}
\hline Scheme / Number of cows & \multicolumn{3}{|c|}{ Vaccination scheme (Age, strain, vaccination) } \\
\cline { 2 - 4 } & $3-6$ months old & $18-20$ months old & After $1^{\text {st }}$ calving \\
\hline $1^{\text {st }} / 5$ & 19 & 19 & $19^{*}$ \\
\hline $2^{\text {nd }} / 5$ & 19 & $19^{*}$ & 82 \\
\hline $3^{\text {rd }} / 5$ & 19 & 82 & $82^{*}$ \\
\hline $4^{\text {th }} / 5$ & 19 & 82 & 82 \\
\hline $5^{\text {th }} / 4$ & 82 & 82 & $82^{*}$ \\
\hline $6^{\text {th }} / 5$ & 82 & & \\
\hline $7^{\text {th }} / 3$ & control & & \\
\hline
\end{tabular}

Note: $*$ - a small dose of the vaccine from strain 82 - 10 bln m.c., vaccine from strain 19 - 3 bln m.c. 
The most important stage was to check the immunity level in cows after the vaccination, pre-immunized according to the following schemes (Table. 4).

For the experiment, all animals were selected in brucellosis-free farms and they were vaccinated with antibrucellosis vaccines according to the indicated schemes.

Before the first vaccination, the animals had a negative reaction. After reimmunization of heifers before insemination, a negative result was also obtained. The examination of the heifers before the third vaccination (after 10 months from the previous vaccination) showed weak reactions only in animals vaccinated according to Schemes 1 and 2: the vaccine from strain 19 was used in the both schemes. Only two cows vaccinated according to Scheme 1 had the immune response detected by AT in the titer of $50 \mathrm{IU}$ and one cow vaccinated according to Scheme 2 had the immune response detected in the titer of $100 \mathrm{IU}$. With such an immune response, animals of all groups were revaccinated and 3 months later, 5 cows from each group were vaccinated subcutaneously with a virulent culture of B. abortus 54 with a dose of 200 million m.c. to check the immunity level. The control group consisted of 3 intact cows. Bacteriological tests were carried out 39 days after the vaccination.

After the vaccination, in most animals, diagnostic indicators of immunological reactions were recorded. The maximum activity of antibody synthesis was observed within 14-28 days. The animals in the control group reacted most actively, which reflected a deeper immunological change due to the development of the infectious process in the body. However, on the whole, specific patterns in the manifestation of immune reactions in animals after vaccination, depending on the scheme of their preliminary immunization, were not found. The results of bacteriological tests are presented in Table. 5 .

Table 5. The results of immunity testing in cows vaccinated against brucellosis according to different schemes

\begin{tabular}{|c|c|c|c|c|c|c|}
\hline \multirow{2}{*}{$\begin{array}{c}\text { Vaccination scheme } \\
\text { (vaccine strain) }\end{array}$} & $\begin{array}{c}\text { Number of } \\
\text { cattle }\end{array}$ & \multicolumn{3}{|c|}{ Infected } & $\begin{array}{c}\text { Number of } \\
\text { immun. } \\
\text { cattle }(\%)\end{array}$ & $\begin{array}{c}\text { Index of } \\
\text { infection }\end{array}$ \\
\cline { 3 - 6 } & & $\mathrm{S}$ & $\mathrm{R}$ & In total & \\
\hline 19 f.d.+19 f.d.+19 sm.d. & 5 & 2 & 0 & 2 & 60 & 10.4 \\
\hline 19 f.d.+19 sm.d. +19 sm.d. & 5 & 1 & 0 & 1 & 80 & 3.2 \\
\hline 19 f.d.+82 f.d.+82 f.d. & 5 & 1 & 1 & 2 & 60 & 2.4 \\
\hline 19 f.d.+82 f.d.+82 sm.d. & 5 & 1 & 1 & 2 & 60 & 2.4 \\
\hline 82 f.d.+82 f.d.+82 f.d. & 4 & 1 & 1 & 2 & 50 & 3.0 \\
\hline 82 f.d.+82 f.d.+82 sm.d. & 5 & 1 & 1 & 2 & 60 & 3.2 \\
\hline Control & 3 & 3 & 0 & 3 & 0 & 24.0 \\
\hline
\end{tabular}

Note: $\mathrm{S}$ - Systemic form of infection, $\mathrm{R}$ - Regional form of infection

The data presented in Table 5 show that there is no significant difference in the immune resistance in animals vaccinated according to different schemes. Obviously, triple immunization, regardless of the vaccine and dose, provided approximately equal immune protection on average in $60 \%$ of animals. It is generally accepted that $50-70 \%$ of the vaccinated animals in the herd are considered a high indicator.

\section{Conclusion}

The experimental materials of the study prove the advisability of using small doses of vaccines from strain 82 in the cattle vaccination schemes against brucellosis. The study proves that revaccination of cows with a small dose of vaccine from strain 82 , regardless of the previous vaccination schemes, ensures approximately the same immunity as the full-dose vaccination schemes. The advantage of the scheme with a ten-time reduced dose of the vaccine from strain 82 is the following: it reduces its reactogenic and agglutinogenic properties, and in addition, it allows cutting down vaccine production volumes and financial expenses of the farmers.

\section{References}

1. B. Osterman, I. Moriyon, International committee on systematic of prokaryotes; subcommittee on the taxonomy of Brucella, Int. J. Syst. Evol. Microbiol., 56(5), 1173-1175 (2006)

2. A. Krasikov, V. Vlasenko, V. Pleshakova, I. Alekseeva, Dynamics of immunological parameters of cattle infected with leukemia virus and its correction with betulin-based medication, in: The Fifth technological order: prospects for the development and modernization of the Russian agroindustrial sector, vol. 393, pp. 25-28 (2019)

3. T. Gerunov, M. Gonokhova, T. Boyko, V. Gerunov, Pathomorphological changes in the organs and tissues of animals during acute Intoxication with neonicotinoids containing nitroso or cyano group, in: Proceedings of the international scientific conference "The fifth technological order: prospects for the development and modernization of the Russian agroindustrial sector," vol. 393, pp. 222-226 (2019)

4. N.N. Maskaev, T.G. Popova, V.V. Tsymmerman, The state of immunity in cows after immunization with brucellosis vaccines according to different schemes, pp. 78-85 (Research materials of VNIIBTZh Omsk, 1990)

5. K.I. Minzhasov, The effectiveness of vaccination of cattle with a vaccine from strain 19 in a small dose, in: Problems of intensification of animal husbandry in Kazakhstan, pp. 75-76 (1986) 
6. K.I. Minzhasov, A.A. Novitsky, V.M. Antyuhov, The unified system of cattle brucellosis prevention in Kazakhstan and Russia (Petropavlovsk, 2007) 307 p.

7. A.A. Novitsky, V.I. Pleshakova, I.G. Trofimov, I.G. Alekseeva, T.I. Lorengel, Areas of Concern of Brucellosis Specific Prevention, Advances in Animal and Veterinary Sciences, 7 (Special Issue 1) 94-99 (2019)

8. A.A. Novickij, K.I. Minzhasov, V.I. Pleshakova, B.R. Kaseinov, R.B. Mahmetova, Infectious diseases of farm animals (KazNIIZhiR Beskol', 2015) 213 p.

9. V.A. Romakhov et al., Epizootological efficacy of a vaccine from strain 19 in a small dose against cattle brucellosis in farms of the Samarkand region of the Uzbek SSR, in: Abstracts of the All-Union Conference, p. 167 (Novosibirsk, 1989)

10. Yu.V. Rusakov et al., Immunity against brucellosis in cattle reimmunized with small doses of agglutinogenic vaccines, in: Actual problems of tuberculosis and brucellosis in agricultural animals (Research materials of VASKHNIL) (Sib. Department, Novosibirsk, 1989) pp. 77-79.
11. A.G. Khlystunov et al., Immunological reactivity of heifers after revaccination with small doses of the vaccine from strains 19 and 104 M (VASKHNIL, IEVSDV, Novosibirsk, 1988) pp. 16-18.

12. K.V. Shumilov et al., Immunization of heifers with a small dose of the vaccine from strain Br. Abortus 104 $M$, Bulletin of VIEV, 51, 71-74 (1983)

13. R.G. Yagudin et al., Production testing of a small dose of vaccine from strain 19 against brucellosis in cattle in the Kustanai region, in: Abstracts of the AllUnion Conference, p. 181 (Novosibirsk, 1989)

14. N.N. Maskaev, R.B. Obosnia, T.G. Popova, V.A. Kokh, Immunological reactions and immunity in cattle vaccinated with anti-brucellosis vaccines in different doses, in: Methods of diagnosis and prevention of animal brucellosis and tuberculosis (Research materials of VNIIBTZh, VASKHNIL, 1988) pp 26-31

15. E. Yudina, S. Konovalov, Development Issues and Prospects of Milk Processing Enterprises, in: Proceedings of the international scientific conference "The fifth technological order: prospects for the development and modernization of the Russian agroindustrial sector," 393, 436-439 (2019) 